Е. Д. ФУРМАН

Rosyjska Akademia Nauk, Moskwa

\title{
Литовский путь к демократии
}

Ц

ель „возвращения в Европу” и построения демократии и рыночной экономики стали общими для посткоммунистических стран Центральной и Восточной Европы. Эту цель преследовали и бывшие советские республики Прибалтики после развала Советского Союза. Но, несмотря на схожесть многих переходных процессов в этих странах, одним из которых стал приход к власти партий социал-демократической ориентации, как „исторических”, так и реформированных бывших коммунистических, каждая из этих стран имела свои собственные для них причины и свой специфический их оттенок. Тем более это касалось Прибалтики, которая была более тесно связана с Советским Союзом, непосредственно находясь в его составе. Однако именно в прибалтийской республике, а именно в Литве, приход бывших коммунистов к власти носил наиболее яркий характер, и в ней же, несмотря на все попытки их партии - Демократической партии труда, вплоть до 2001 г., они не могли называться социал-демократами.

„Перестройка” положила в Литве начало процессу выхода на поверхность всего накопленного за годы советской власти протестного потенциала. Благодаря тому, что среди населения республики подавляющее большинство составляли литовцы (79,6\%), Литва изначально, в отличие от Эстонии и Латвии, где доля национальных меньшинств составляла 61,5 и 52\% соответственно, смогла избежать раскола общества по этническому признаку, который в условиях национального возрождения приобретал политический характер ${ }^{1}$. Как следствие, демократизация, а затем и достижение независимости, получили здесь практически всеобщую поддержку.

Разрозненные выступления диссидентов в Литве уже к лету 1988 г. переросли в массовое движение „Саюдис” („Движение”), которое возглавила интеллигенция, элита литовского общества, большая часть

1 „Советская Литва” 1990, 3 марта. 
из которой представляла собой вильнюсских гуманитариев. В течение лета численность участников организованных этим движением митингов поднялась от 50 тысяч человек в июне до сотен тысяч в июле и августе. Делегаты Учредительного съезда „Саюдиса”, прошедшего в октябре того же года в Вильнюсе, были избраны „группами поддержки" этого движения на предприятиях, прежде всего, Вильнюса и Каунаса и в различных творческих, культурных и общественных организациях, некоторое количество мест было зарезервировано для духовенства и диссидентской организации „Лига свободы Литвы” (ЛСЛ).

В принятой Учредительным съездом программе „Саюдис” заявил, что „считает национальное самосознание и самовыражение независимыми ценностями и важным фактором общественного возрождения”". От диссидентских документов программа „Саюдиса” отличалась не направленностью, а степенью радикализма. Но вместе с тем, она не очень сильно отличалась и от программных позиций ЦК Коммунистической партии Литвы (КПЛ), где к этому времени уже сменилось руководство, а новый первый секретарь А. Бразаускас даже присутствовал на Учредительном съезде.

В Литве, где среди членов компартии литовцы также составляли подавляющее большинство - 71\% (в Эстонии - 50\%, в Латвии $40 \%$ ), значительная часть местной номенклатуры, давно уже утратившая веру в официальную идеологию, тяготилась своим положением и стремилась к большей самостоятельности от Москвы (а если возможно, то и к полной самостоятельности республики). Единственное, что её могло удерживать от открыто антисоюзной позиции - это страх потери власти, статуса и доходов, которые зависели от положения в партийной иерархии, возглавляемой руководством в Москве. При этом, разумеется, нельзя сводить всё к мотивам выгоды многие представители номенклатуры искренне разделяли комплекс национал-демократических идей, ощущали себя патриотами, думающими о благе Литвы.

Тем не менее, усилению либерального крыла литовской компартии и приходу его к власти помогла сама Москва. Горбачевское руководство, не представляя себе потенциала литовского национализма, вначале увидело в создании „Саюдиса” (и „народных фронтов”

2 „Atgimimas” 1988, 15.10, № 3, p. 6-7. 
в других республиках) развитие идей „перестройки”, пробуждение здоровой инициативы снизу. Для московских и литовских партийных либералов, естественно, было лучше, чтобы соответствующие инициативы исходили от „умеренного” „Саюдиса”, значительная часть лидеров которого состояла в партии, нежели от неконтролируемых диссидентов. Во время своего приезда в августе 1988 г. в Литву А. Яковлев, ближайший соратник Горбачева в Политбюро, убеждает руководство КПЛ смелее идти по пути „перестройки”, поддержать „Саюдис" и даже использовать „национальный фактор” для ускорения процесса реформ. Этот визит дал „Саюдису” зеленый свет и настолько повлиял на дальнейший ход событий, что впоследствии некоторые деятели „Саюдиса” стали выделять периоды „до” и „после" Яковлева. Вскоре Москва назначает новым литовским партийным руководителем - одного из секретарей ЦК, первого из партийного руководства, кто стал посещать митинги, организованные „Саюдисом”, - А. Бразаускаса. Вместо второго секретаря Н. Митькина, представителя „номенклатуры Москвы”, был избран тоже русский по национальности (назначение русских вторыми секретарями в союзные республики было неформальным, но всегда жёстко соблюдавшимся правилом), но родившийся и выросший в Литве В. Березов.

Но сама же Москва и нарушила установившийся с приходом Бразаускаса и Березова „медовый месяц” в отношениях партийного руководства и „Саюдиса”.

После принятия в ноябре 1988 г. Верховным Советом Эстонии Декларации о суверенитете, согласно которому всесоюзные законы входят в силу только после того, как будут ратифицированы Верховным Советом республики, Бразаускас был немедленно вызван в Москву с целью предупредить развитие событий в Литве по эстонскому примеру. Первый секретарь КПЛ обещает этого не допустить. Как пишет А. Ливен, „в октябре 1988 г. у Бразаускаса сдали нервы” 3.

Эйфорическое единство в любом случае подорвал бы неизбежный конфликт с Москвой. Пока в ЦК КПСС не сопротивлялись поднимающемуся литовскому национализму и чуть ли не приветствовали его, республиканскому партийному руководству было легко сочетать внешнюю лояльность Москве с дружбой с „Саюдисом”

3 A. Lieven, The Baltic Revolution. Estonia, Latvia, Lithuania and the Path to Independence, London 1993, p. 227. 
и все чаще звучавшими заявлениями о стремлении к независимости, про которые в любой момент можно сказать, что имеется в виду лишь самостоятельность в составе СССР. Но раньше или позже Москва должна была оказать сопротивление, и в этом случае литовское руководство уже не осмеливалось противостоять ей.

Вызванное этим возмущение „Саюдиса” было тем более сильным, что к тому времени он, как и литовское общественное мнение в целом, значительно радикализировался. „Саюдису” уже невыгодно было подчёркивать свою верность ,идеалам перестройки” и единение с КПЛ. Напротив, выгоднее стало подчёркивать своё отличие от „партократов”. Кроме того, всё яснее вырисовывалась перспектива свободных выборов, и в их преддверии борьба за влияние в обществе начинала осознаваться как борьба за потенциальные голоса, за перспективу обретения реальной власти. „Саюдис” начинал понимать, что у него есть возможность прихода к власти и что в борьбе за такую власть КПЛ - конкурент. Этот процесс сопровождался и изменением соотношения сил в руководстве самого „Саюдиса”. Как уже указывалось, поначалу в нём доминировали вильнюсцы, столичная гуманитарная элита - более „космополитическая”, с большими связями в номенклатурной партийной верхушке и на Западе и не видевшая в „Саюдисе” способ поднять свой (и без того высокий) социальный статус. Постепенно, однако, всё большую роль начинали играть каунасцы, в основном - представители более „низовой”, технической интеллигенции, для которых „Саюдис” объективно представлялся средством подняться по социальной лестнице ${ }^{4}$. В целом каунасцы всегда были радикальнее и культурно ориентированными скорее на старую, досоветскую Литву, чем на Запад. Уже на Учредительном съезде „Саюдиса” в октябре 1988 г. можно было видеть рост влияния каунасских радикалов и их различия с вильнюсской группой. Один из каунасцев, популярный композитор Р. Паулаускас на этом съезде первым публично призвал к борьбе за полную независимость.

Несмотря на то, что осенью 1988 г. КПЛ одно за другим принимала множество постановлений, ещё год назад представлявшихся невозможными и воплощавших самые смелые национальные мечты,

4 „Разница между ними и вильнюсской интеллигенцией”, - пишет А. Ливен, - „отражала древнюю культурную напряженность между относительно плюралистическим Вильнюсом и этнически чистым Каунасом” (A. Lieven, op. cit., p. 226). 
теперь, после ее отказа принять суверенитет, всё это казалось уже недостаточным. К тому же не следует забывать, что процессы, происходящие в любой из стран Балтии, всегда влияют друг на друга. Эстонцы со своей Декларацией о суверенитете вырвались в то время вперёд, и то, что Литва не последовала их примеру, „Саюдис” расценивал как настоящий позор.

Проявленная Бразаускасом готовность к компромиссу с Москвой вызвала кризис в избранном на Учредительном съезде Совете „Саюдиса”, резко обострив отношения между „вильнюсскими либералами” и „каунасскими радикалами”. Последние отныне стремились к тому, чтобы „Саюдис” максимально отмежевался от КПЛ.

В таких условиях Совет принимает решение „сплотить ряды”. Утверждается декларация „морального единства”, провозглашающая, что все несогласные с литовским суверенитетом члены Совета Сейма будут исключены из рядов движения. Это практически устанавливало его независимость от компартии. Было также принято решение ввести в „Саюдисе” институт формального членства. Председателем „Саюдиса” Совет избрал профессора музыковедения Вильнюсской консерватории В. Ландсбергиса (что важно для того времени - не члена КПСС), представлявшего собой компромиссную для обеих группировок фигуру.

Возникнув как аморфное общенациональное движение с расплывчатыми целями, стремившееся сплотить всех и никому при этом не противостоять, „Саюдис” постепенно начал, таким образом, трансформироваться в политическую силу, имеющую собственное лицо и противостоящую другой политической силе - КПЛ Бразаускаса. Общенациональное движение стало превращаться в одну из основных партий республики.

Выборы народных депутатов СССР в марте 1989 г. принесли победу „Саюдису” (из 42 депутатских мандатов на выборах народных депутатов его члены завоевали 36). Все литовские политические силы от ЛСЛ до КПЛ противостояли в тот период „Единству”, организации, созданной в защиту прав национальных меньшинств, прежде всего русского, и, как следствие этого - промосковской. Не имея большого политического влияния, она, тем не менее, рассматривалась в качестве настоящего внешнего врага, но действовавшего изнутри, „Пятой колонной”.

И КПЛ, и „Саюдис” шли на выборы под лозунгом: „Литва без суверенитета - это Литва без будущего", и хотя расшифровывался 
ими такой лозунг по-разному, само по себе это различие заключалось лишь в степени радикальности и откровенности. Если КПЛ, рассуждая о суверенитете, упоминала „ленинскую советскую федерацию”, то „Саюдис” высказывался на этот счет резче и откровеннее о „неотъемлемом праве на восстановление независимой Литвы”, хотя открыто выдвигать требование о выходе из СССР еще не решался.

Сразу после выборов поражение КПЛ Березов объяснил тем, что „избиратели прежде всего категорически проголосовали против старых времен и порядков”, а партия не смогла стряхнуть с себя ответственность за „старые ошибки”. Фактически он обозначил дальнейшее направление эволюции КПЛ - постепенное освобождение от груза прошлого, но освобождение, при котором партия всё же не исчезает, а преобразуется в партию нового типа, способную к конкурентной борьбе в условиях демократии.

Особенность литовской ситуации заключалась в том, неприятие населением компартии отнюдь не распространялось на ее руководство. В широких слоях народа предпочтение упорно отдавалось именно ее руководителям, а не лидерам оппозиции. Бразаускас, подкупающий своей простотой, близостью к народу, образом настоящего хозяина, постоянно (кроме периода, последовавшего за событиями января 1991 г.) шёл впереди Ландсбергиса, отталкивавшего массу простых литовцев своей подчёркнутой нетерпимостью и высокомерием.

У Бразаускаса и КПЛ, таким образом, имелись неплохие шансы удержать власть на предстоявших в феврале 1990 г. выборах в Верховный Совет Литвы. Однако для этого надо было избавиться от коммунистического „ярлыка” и от образа организации, подчинённой московскому центру.

В этих целях после выборов народных депутатов СССР и в преддверии выборов в Верховный Совет Литвы Бразаускас и КПЛ предпринимают целую серию шагов, главным из которых становится принятие Декларации о государственном суверенитете республики (от чего Бразаускаса отговорили в Москве осенью 1988 г.). Принимается также закон об экономической автономии, в отношении

5 „Комсомольская правда”, Вильнюс 1989, 30 марта. 
которого согласие между компартией и „Саюдисом” было достигнуто еще осенью 1988 г.

Бразаускас уже не боится открыто идти на конфронтацию с Москвой. На сентябрьском пленуме ЦК КПСС он заявил, что „нынешний статус компартий союзных республик не соответствует правовому положению союзных республик в Союзе ССР",. И в декабре на своем $\mathrm{XX}$ съезде КПЛ 855 голосами против 135 принимает решение о выходе партии из КПСС. Съезд одобрил также новую программу, которая отказывалась от коммунистической идеологии и провозглашала основной целью партии создание независимой демократической Литвы. Позднее, в декабре 1990 г. на внеочередном съезде КПЛ отказалась и от прежнего названия, став отныне Демократической партией трудящихся Литвы ${ }^{7}$.

По результатам опросов независимая КПЛ в течение декабря 1989 г. резко набрала популярность среди литовского населения и к концу месяца обгоняла „Саюдис” (+ 79, по сравнению с + 65 у „Саюдиса”)

Как и прежде, главной целью „Саюдиса” на выборах в Верховный Совет в феврале 1990 г. было не допустить в парламент сторонников СССР (членов „Единства” и отколовшейся от независимой литовской компартии „КПЛ на платформе КПСС”). В сравнении с этой „общенациональной” задачей соперничество между КПЛ и „Саюдисом" становилось второстепенным. Между ними было заключено „джентльменское соглашение”, согласно которому кандидаты-коммунисты, выступавшие за независимость, и кандидаты от „Саюдиса” обязывались не слишком соперничать друг с другом. Голосование в одномандатных округах, при котором побеждал кандидат, набравший простое большинство голосов, всегда выгодно крупным партиям. На этот раз все оказалось на руку прежде всего „Саюдису”. Поддерживавшиеся им кандидаты получили 51\% мест (72 из 141). Вскоре этот процент возрос до 68\% (96 мест), поскольку к „саюдисскому”

${ }^{6}$ См.: Союз можно было сохранить. Белая книга. Документы и факты о политике М. С. Горбачёва по реформированию и сохранению многонационального государства, М. 1995, с. 78-79.

7 Меньшинство делегатов, голосовавшее против решений съезда, так называемая „ночная” партия во главе с Бурокявичусом, провозгласили себя „КПЛ на платформе КПСС”. Как и „Единство”, КПЛ (КПСС) не имела какой-либо значительной поддержки среди населения Литвы и после распада СССР вообще полностью исчезла с политической сцены.

8 „Летувос Ритас” 1990, 9 января. 
большинству примкнули ряд беспартийных депутатов и депутатов от независимой КПЛ. Кроме того, к ним присоединились представители появившихся в этот период новых партий, еще не вполне размежевавшихся с „Саюдисом” и получивших на выборах в целом 18 мандатов ${ }^{9}$. Членов независимой КПЛ среди депутатов насчитывалось 46 человек (позже 18 депутатов вышли из нее ${ }^{10}$. КПЛ на платформе КПСС получила $13 \%$ голосов избирателей и только 4\% мест (6) ${ }^{11}$.

Хотя выборы принесли полную победу сторонникам независимости, первоначально никакого ясного плана ее достижения не существовало. Ландсбергис, отражая мнение большинства депутатов, считал, что вопрос о принятии декларации о независимости не может обсуждаться, пока им не будут проведены международные консультации. В конце концов, однако, он поддался давлению радикалов, умело сыгравших на его властолюбии и честолюбии. Представители каунасской фракции предлагали поддержать выдвижение кандидатуры Ландсбергиса на пост председателя Верховного Совета, а кандидатуры К. Прунскене (в свое время члена Инициативной группы „Саюдиса”, а на тот момент - заместителя председателя Совета министров) - на пост премьер-министра в обмен на немедленное принятие декларации. Кроме всего прочего, Ландсбергис прекрасно понимал, что принявшие участие в подписании Декларации о независимости автоматически записывались в историю страны, особенно это касалось лидера национального движения.

11 марта 1990 г. новоизбранный Верховный Совет в тщательно выстроенной серии голосований принял „Акт о восстановлении независимого Литовского государства". В тот же день депутаты выбрали Ландсбергиса председателем Верховного Совета, который, при отсутствии избранного народом президента, является главой государства. Премьер-министром стала Прунскене. Начиналась эпоха господства „Саюдиса”.

Такой революционный шаг, как провозглашение независимости и выход из СССР, диктовал Литве не менее решительные действия и в

9 Социал-демократическая партия получила 9 мандатов, 4 мандата оказались у „Партии зеленых”, 3 - у Демократической партии Литвы, 2 мандата получила Христианско-демократическая партия. (См.: R. Taagepera. The Baltic States, „Electoral studies. Special issue” 1990, v. 9, № 4, p. 306).

${ }_{10}$ Nepriklausomybes ir Demokratijos zingsniai, Vilnius 1999, p. 23.

11 R. Taagepera, op. cit., p. 306. 
дальнейшем. Смена власти здесь оказалась более радикальной, чем где бы то ни было. В Эстонии и Латвии, хотя премьерами там становились представители Народных фронтов, председатели Верховных советов оставались прежние представители лояльной националистам, но осторожной номенклатуры - Горбуновс и Рюйтель. В Литве же старая элита была почти полностью отстранена от рычагов управления республикой, и вся власть перешла к „Саюдису”. Коммунистические лидеры заняли в правительстве лишь второстепенные посты. Бразаускас стал заместителем Прунскене. Но и это назначение, а также включение в правительство ряда других чиновников-коммунистов, скорее мотивировалось саюдистами не признанием роли КПЛ в литовском обществе, а необходимостью сохранять все же каналы связи с Москвой. „Возможно, при более благоприятных обстоятельствах, - пишет В. Гайдис, - прежняя элита могла трансформироваться и адаптироваться к новым условиям, но жесткая политическая конкуренция оставила очень мало незанятых позиций и потребовала строгого отбора, подразумевающего, в том числе, и отречение от членства в прежней элите. В результате, старая элита вынуждена была объединиться и действовать согласованно. Постсоветская Литва дала рождение биполярной элите: элите левых (группа Бразаускаса) и элите правых (группа Ландсбергиса),"12.

Выше уже отмечалось специфическая раздвоенность настроений литовских избирателей, среди которых был непопулярен „ярлык” КПЛ и в то же время популярны ее лидеры, прежде всего Бразаускас, и наоборот - популярен ,ярлык” Саюдиса, но непопулярны его лидеры. После выборов литовские избиратели попались в своего рода ловушку. Большинство из них совсем не желало видеть в роли главы государства Ландсбергиса ${ }^{13}$.

В марте 1990 г. КПЛ собрала десятки тысяч подписей под петицией, требующей переизбрания Бразаускаса, но на парламент это не произвело никакого впечатления. Между тем, в апреле в Литве был проведен опрос общественного мнения. Отвечая на вопрос, поддер-

12 Gaidys V. The Emergence of the Lituanian Political Elite. Dallas. 1999. P. 124.

13 Ю. Новагроцкене пишет, что „в 1990 году народ голосовал за «Саюдис» как средство осуществления независимости, и за А. Бразаускаса как главу государства". (J. Novagrockiene, From political differentiation toward stabilization of Lithuanian party system, „Social Studies”, v. 4, Streaming Toward Social Stability, Vilnius-Tampere 2000, p. 171). 
живаете ли вы быстрые, но более болезненные реформы, или более умеренные и постепенные, только 23\% литовцев поддержали первый вариант. Большинство же оказалось, по сути, на стороне платформы Бразаускаса. (Для сравнения: в Эстонии проведение быстрых реформ поддержали $43 \%$ респондентов) $)^{14}$.

Но на ситуацию в Литве вновь повлияла реакция Москвы. Горбачев как раз в тот момент предъявил ей ультиматум с требованием отмены парламентом декларации о независимости. 16 апреля Москва объявила о введении экономической блокады Литвы, приостановив поставки нефти и бензина и дав разрешение только на поставку $20 \%$ природного газа. Были запрещены также поставки ряда других товаров, в том числе кофе и сахара, которые могли продаваться за твердую валюту.

Но все эти меры оказались слишком запоздалыми и потому контрпродуктивными. Реальная внешняя угроза только сплотила литовское общество. „Те, кто сразу после принятия декларации критично относились к Ландсбергису, стали его решительными сторонниками, и демонстрации вернулись к своим прежним, до провозглашения независимости, масштабам"15.

Блокада явилась тяжелым экономическим испытанием. Кроме того, западные политики (мнение которых всегда было исключительно важным для Ландсбергиса) убеждали литовцев пойти на переговоры с Москвой. В конце концов, 29 июня Лансбергис, возложив всю ответственность за это решение на премьер-министра Прунскене, соглашается на „мораторий” декларации 11 марта. После этого блокада Москва сняла блокаду Литвы, но процесс переговоров серьезно затягивался. Фактически обеим сторонам отступать было некуда. Руководство СССР понимало, что согласие на независимость Литвы вызовет цепную реакцию и распад Союза. Литовские же руководители не могли позорно отказаться от Декларации о независимости.

В такой напряжённой ситуации у Ландсбергиса возникает стремление собрать все силы и превратить „Саюдис” в настоящую, дисциплинированную партию. На втором съезде 21-22 апреля 1990 г. из названия движения было исключено слово „перестройка” и оно

14 V. Gaidys, Political, party preferences and political identities in Lithuania, „Social Studies”, v. 2, Changes of identity in modern Lithuania, Vilnius 1996, p. 90.

15 A. Lieven, op. cit., p. 239. 
стало называться „Саюдис Литвы”. Когда на съезде был поднят вопрос о дальнейших перспективах развития, Ландсбергис обозначил два возможных пути: „или „Саюдис” станет более жесткой, узкой организацией, другими словами - оформится как партия с четко обозначенной структурой, или он будет вечной оппозицией, но это будет означать, что ему время от времени придется изменять направление своей деятельности, каждый раз всё начиная сначала. В таком случае... движение превратилось бы в экспериментальную лабораторию"

Съезд, однако, не поддержал Ландсбергиса. Большинство „Саюдиса" не желало введения новой партийной дисциплины и опасалось его превращения в авторитарную организацию во главе с лидером, непопулярным не только среди населения, но и среди многих членов самого движения. На съезде были приняты новые программа и устав. В. Ландсбергис оставил пост председателя Совета сейма „Саюдиса”, а его новым председателем был избран историк Й. Тумялис.

Одновременно с этим в парламенте происходил процесс быстрого размежевания депутатов. Появившиеся фракции стремились заполнить ту брешь, которая образовалась между стремлением населения к независимости и его одновременным нежеланием идти на радикальные перемены и острый конфликт с Москвой. Началось оформление новых, стремящихся сочетать эти устремления центристских сил. Но, несмотря на начавшийся распад „Саюдиса”, основное противостояние политической элиты в 1990 г. все же происходило не внутри него и даже не между „Саюдисом” и КПЛ, а между большинством Верховного Совета и правительством Прунскене. Пытаясь справиться с экономическими трудностями, правительство стремилось сохранить экономические и политические связи с СССР и в результате подпадало под подозрение в тайных переговорах с Москвой и в готовности поступиться литовской свободой ${ }^{17}$.

16 „Эхо Литвы” 1990, 24 апреля.

17 Конфликт парламента и правительства в значительной мере был вызван неопределённостью полномочий того и другого, что в этот период было характерным противостоянием ветвей власти на фоне постоянно и резко ухудшавшегося экономического положения не только для Литвы, а для всего бывшего Советского Союза. Правительство требовал для себя новых полномочий, а парламент стремился к полному над ним контролю. 
Внутреннее и международное противостояние на протяжении осени и начала зимы 1990 г. продолжало нарастать. В декабре конфронтация правительства и парламента достигла своего пика из-за решения исполнительной власти повысить потребительские цены. Это привело ко второму, еще более крупному кризису, который закончился военным вмешательством Москвы. Советские воздушно-десантные войска захватили ряд стратегически важных зданий Вильнюса, а 13 января 1991 г. произвели штурм столичной телебашни, в результате которого 14 человек погибли и более 500 были ранены.

Январские события оказались „звёздным часом” для Ландсбергиса. „Не будучи смелым по природе, он волевым усилием и благодаря своему патриотизму стал исключительно храбрым”, - пишет Ливен $^{18}$. Ландсбергис добился тогда необычайной популярности, которую ему удалось удерживать на протяжении почти всего года, в то время как Бразаускас, никак себя не проявив в те роковые дни, в течение того же года ее утратил.

Во всесоюзном референдуме относительно судьбы СССР 13 марта 1991 г. Литва участвовать отказалась и вместо этого провела свой референдум, в котором приняли участие $84,43 \%$ избирателей. $90,47 \%$ из них выразили желание жить в независимой, демократической стране ${ }^{19}$.

К тому времени стало очевидно, что Москва уже не решится подавить национальное литовское движение силой: это означало бы крах всей политики „перестройки”. 22 января, выступая по телевидению в связи с событиями в Литве, Горбачёв заявил, что любые самовольные действия войск недопустимы. А после неудачной попытки августовского путча в Москве 6 сентября 1991 г. СССР сам признает независимость трех прибалтийских республик.

Цель достижения независимости объединяла подавляющее большинство литовского общества. Наличие этой цели девальвировало, отодвигало на задний план все разногласия, кроме расхождений по вопросу о методах её достижения. Теперь, после получения независимости, ситуация радикально изменилась. Казалось бы, старые линии размежевания должны были исчезнуть. Но этого не произошло.

18 A. Lieven, op. cit., p. 232.

19 Svarbiausiu Lietuvos ivykiu zinynas. 1990-2001, Vilnius 2001, p. 26. 
За старыми размежеваниями относительно путей завоевания независимости стояло значительно больше, чем просто отношение к этому вопросу. Разногласия по этому вопросу были лишь одним из проявлений значительно более глубоких социальных, психологических и культурных различий. Поэтому с разрешением основной проблемы размежевания не исчезли, а лишь приняли новые формы. При этом борьба становилась даже более ожесточённой, поскольку перестала сдерживаться необходимостью совместно противостоять общей опасности.

После сентября 1991 г. в парламенте возникли два блока. Один из них находился в оппозиции к Ландсбергису и правительству Вагнорюса, сформированного сразу после январских событий, другой правительственный, „саюдистский” блок. И в том и в другом, с учетом изменений позиций депутатов и „парламентских миграций”, насчитывалось по 50-56 парламентариев. Оппозиция, таким образом, была на грани превращения в парламентское большинство.

Ситуация осложнялась всё усиливающимися конфликтами внутри правительства. Добившиеся своей главной политической цели, лидеры периода завоевания независимости не очень-то подходили для решения вопросов „мирного времени” - строительства нового государства. В большинстве своем они имели гуманитарное образование, не располагали опытом административного управления, и проблемы государственного строительства и хозяйственного управления интересовали их куда меньше, чем вопросы культуры, символики и исторического прошлого. Не слишком разбирающиеся в вопросах экономики и управления, очень идеологизированные и амбициозные, они были совершенно не готовы к совместной командной работе. В результате правительство стали раздирать склоки.

Основные вопросы, которые теперь разделяют всё уменьшающееся парламентское большинство и всё усиливающуюся оппозицию, касаются, прежде всего, будущего государственного устройства и отношения ко всё более чётко обозначавшейся авторитарной перспективе. Только на сей раз эта перспектива была связана уже не с угрозой „коммунистического реванша”, а с довольно четко обозначившимися устремлениями новой, „демократической” власти.

Возводя в идеал досоветскую Литву, Ландсбергис ориентировался на одного из самых ярких лидеров той эпохи - авторитарного правителя Сметону. „Нет никаких сомнений”, - пишет Ливен, - „что профессор Ландсбергис, литовский лидер в период между 1990 
и 1992 гг., считал себя в какой-то мере политическим наследником Сметоны. Он с восхищением говорил о нем в своих речах и перенял частично его символику... Мягкие манеры и в то же время ум и упорство Сметоны напоминали отчасти черты самого Ландсбергиса, но, к сожалению, с одной разницей. Сметона был довольно способным администратором с длительным опытом работы. Ландсбергис, хотя и трезвый политический тактик, по свидетельству членов его собственной команды, совершенно не интересовался вопросами администрации, финансов и законодательства, предпочитая иностранные визиты, символику и литовскую культуру, которую он глубоко любил"20. Характерно, что в ту пору Ландсбергис уже нигде не появлялся без телохранителей из „каунасского спортивного клуба”, в которых оппозиция усматривала зародыш военизированной организации, непосредственно подчиненной новоявленному „вождю”.

Временный Основной закон 1990 г., отдавая власть Верховному Совету, предполагал наличие стабильного парламентского большинства и общего политического консенсуса. Но к концу 1991 г. стабильность и единодушие в Верховном Совете исчезли, и возник „парламентский тупик”. Выход из него Ландсбергис видел в введении института сильного, независимого от парламента президента, которым, естественно, должен был стать он сам, и в превращении „Саюдиса” в сплочённую партию, опору всевластного президента.

В декабре того же года прошел III съезд „Саюдиса”, на котором обозначились тенденции, которые вполне можно было бы назвать „фашизоидными”. В своей речи на съезде Ландсбергис провозглашает три высшие ценности, среди которых отсутствовала демократия, - „честный труд, семья, родная земля” (почти полное повторение лозунга профашистского маршала Петэна - „труд, земля, родина”). Текст его выступления был насыщен такими выражениями, как „саботаж”, „воровство”, „измена”. На этом же съезде были выдвинуты новая программа и устав, а также требование о введении в Литве поста президента. Кандидатом от „Саюдиса” на этот пост был предложен Ландсбергис, избранный его почетным председателем.

Оппозицию авторитарным тенденциям „саюдистов” возглавила ДПТЛ, в свою очередь выдвинувшая идею установления парламент-

${ }^{20}$ A. Lieven, op. cit., p. 68. 
ской республики. В этом вопросе ее поддержали и многие правые. Созданная представителями каунасских националистов в начале 1992 г. „Фракция национального прогресса” выступила против курса Вагнорюса и Ландсбергиса и требований сильной президентской власти.

Двойственность цели проводившихся в Литве преобразований достижение одновременно независимости и демократии - привела к парадоксальным последствиям. Борьба за независимость, объявлявшая основным противником Москву и все советское, как показала практика, исключала при этом демократию.

Ландсбергис и преобразованный „Саюдис” между тем продолжали разжигать антикоммунистическую истерию. Фактически, они всеми силами старались сохранить ту атмосферу „осаждённой крепости”, в которой Литва жила в 1990-1991 гг. Им нужны были враги и после того, как реальная угроза со стороны Москвы исчезла. Теперь такими врагами были объявлены бывшие коммунисты, ДПТЛ и повсюду разыскивавшиеся ,тайные агенты КГБ”.

Съезд „Саюдиса” принял постановление, что отныне в его ряды не могут быть приняты члены Демократической партии труда и бывшие функционеры КПЛ. В законодательство был включен пункт, предусматривавший национализацию собственности коммунистической партии, причем администрацией Вагнорюса это интерпретировалось и как национализация собственности ДПТЛ.

Протесты ДПТЛ по поводу конфискации двух ее газет - Вальстечю лайкраштис (Крестьянская газета) и Кауно айдас (Эхо Каунаса) получили поддержку большинства независимой прессы республики, которая приняла участие в декабрьской забастовке, с полным основанием опасаясь, что начатые правительством конфискации в конечном итоге могут быть направлены против всей оппозиционной печати.

Одновременно началась широко разрекламированная охота на „агентов КГБ”. Осенью был проведен закон, потребовавший, чтобы все прежние информанты и сотрудники КГБ раскрыли себя. Этим людям было запрещено в течение пяти лет занимать ключевые посты и руководящие позиции в правительстве. Одновременно была создана парламентская комиссия по проверке связей депутатов и КГБ. И здесь власть попала впросак. Комиссия, объявила, что тайным агентом был и Чепайтис, личный советник Ландсбергиса и основатель Независимой партии (созданной в июне 1990 г. с расчетом сохранить массовую поддержку для „саюдистской” коалиции). Депутаты Минкявичус и Прунскене позже также будут обвинены 
в подобном сотрудничестве. Оказавшись в замешательстве от этих разоблачений, коалиция „Саюдиса” стала добиваться расширения категории тех людей, которые должны быть исключены из правительственной службы. В нее были включены бывшие политические работники военной и милицейской служб и всех гражданских организаций, а также бывшие коммунисты, занимавшие ответственные посты в партийных органах всех уровней, в профсоюзах, академических и научных институтах и т.д.

Эти меры привели к возникновению широкой коалиции, находившейся в оппозиции предложенному закону. В ней объединились бывшие коммунисты фактически из всех фракций Верховного Coвета. К весне 1992 г. попытка „десоветизации” была похоронена.

Поиски врагов и их искусственное создание не ограничились коммунистами. Ландсбергис попытался сыграть и на традиционных для Литвы антипольских чувствах. Несмотря на то, что после сентября 1991 г. какая-либо угроза польского сепаратизма исчезла (местное самоуправление двух польских районов страны к юго-востоку от Вильнюса и в городе Снечкус, где преобладало русское население, с марта 1990 г. по август 1991-го препятствовало выполнению законодательных актов и правительственных указов), правительство отказывается отменить в них прямое правление Вильнюса. Естественно, что в результате этого поляки и русские практически полностью перешли на сторону оппозиции. Но и разбудить антипольские и антирусские чувства литовцев Ландбергису тоже не удаётся. Этническая ситуация в Литве, как уже говорилось, резко отличается от положения в Эстонии и Латвии. Удельный вес меньшинств не так велик, особо важных социальных позиций они не занимают и особого страха у литовского населения не возбуждают.

Кроме того, Ландсбергис и Вагнорюс, скорее из догматически-антисоветских, чем из каких-либо собственно экономических соображений, стремятся к полному уничтожению колхозов и госхозов и ещё летом 1991 г. проводят закон о реституции, включающий и возвращение земли довоенным владельцам. Это вызывает резкое недовольство сельского населения, которое не может ослабить даже агитация за новый закон католического духовенства. „Саюдис” заявляет, что деколлективизации препятствуют „красные” председатели колхозов, цепляющиеся за свои посты. Но председатели колхозов и директора госхозов получают поддержку простых крестьян.

Становится все более очевидным, что Ландсбергис ориентирован на досоветское прошлое. Он стремится продолжать борьбу в то вре- 
мя, когда общество хочет успокоиться после страшных потрясений 1990-1991 гг.. Итогом становится объединение против него мощных общественно-политических сил. Это не только ДПТЛ, но и те правые, которые видят будущую Литву демократическим государством и не желают нового издания диктатуры Сметоны. Это - все бывшие коммунисты, к какой бы партии в данный момент они ни принадлежали. Это - все меньшинства и прежде всего - поляки и русские. Это - значительная часть СМИ, как правых, так и левых, опасающихся новой цензуры. Это, наконец, - литовское крестьянство, руководимое председателями колхозов и директорами совхозов.

На референдуме 23 мая конституция, предусматривавшая сильную президентскую власть, была отвергнута: проголосовать пришло только 57,5\% избирателей, „за” высказалось 69,4\%. Это составило всего 39,9\% всех избирателей, в то время как для ее принятия требовалось набрать более $50 \%$ голосов ${ }^{21}$.

Ландсбергис тут же обвинил своих оппонентов в проведении „ползучей революции”, тёмных заговорах и интригах. Однако обстановка в стране складывалась таким образом, что в июле 1992 г. правительству Вагнорюса пришлось уйти в отставку.

Новый проект Конституции, референдум по которой был намечен на октябрь, одновременно с выборами нового парламента, также предусматривал введение поста президента, избираемого народом, а не парламентом. Но в этом новом варианте президент должен был обладать значительно меньшими полномочиями, чем в проекте „Саюдиса", вынесенном на майский референдум.

Выборы и референдум по Конституции в октябре 1992 г. проходили в условиях глубочайшего кризиса литовского общества.

Экономическое положение Литвы было близким к катастрофе. В течение года производство сократилось на 51,6\%. Для ситуации в республике показателен такой факт: к октябрю 1992 г. большинство семей получали горячую воду только два раза в неделю, а некоторые не имели ее вообще. Отопление было включено только в середине октября, на две недели позже, чем обычно, и ограничивалось 13 градусами по Цельсию 22.

Естественно, что все те вопросы, которые были так важны для „Саюдиса” и самого Ландсбергиса - вопросы скорее политического

21 „Летувос ритас", 1992, 29 мая - 5 июня.

22 A. Lieven, op. cit., p. 72. 
и культурного характера, - для большинства населения отошли на второй план. Людей прежде всего волновали проблемы их личного выживания. На вопрос социологической лаборатории Вильнюсского университета о том, какие вопросы наиболее актуальны для Литвы, 64\% опрошенных назвали экономические, и только $21 \%$-политические ${ }^{23}$.

Судя по всем опросам, возвращения к советским временам подавляющее большинство не желало. Но сами эти времена всё больше начинали окрашиваться в радужные и ностальгические тона.

В октябре проект Конституции был одобрен 75,42\% участвовавших в референдуме (56,76\% всех граждан Литовской республики, имевших на тот момент право голоса). Таким образом, с 25 октября проект конституции становится Основным Законом Литовской республики.

На парламентских выборах большинство получили представители ДПТЛ - 73 мандата (44,4\% голосов). Коалиция „Саюдиса” смогло завоевать всего 30 мандатов, получив 20,9\% голосов ${ }^{24}$.

С ДПТЛ в парламент пришли люди совершенно иного типа, чем те, которые преобладали в старом Верховном Совете. Эпоха безраздельного господства интеллигенции кончилась. Среди кандидатов, а затем и депутатов от ДПТЛ преобладали жители литовской „глубинки”, выходцы из деревни и люди старшего возраста. Теперь только 7\% депутатов - жители Вильнюса, а $46 \%$ - уроженцы деревень ${ }^{25}$. Средний возраст депутатов - 52 г. $^{26}$

23 „Летувос ритас" 1992, 31 января - 7 февраля.

24 В какой-то мере на этих выборах проявилось стремление оставить в прошлом главный идеологический конфликт уходящего периода, когда занять прочное место в партийной системе Литвы смогли христианские демократы и социал-демократы, получившие соответственно 12,4 и $6 \%$ голосов и образовавшие свои парламентские фракции. В успехе этих партий можно было увидеть желание избирателей отойти от выбора между двумя „крайностями” - ДПТЛ и „саюдистами”. Союз поляков и Партия независимости получили по 4 мандата, и по двум мандатам - Движение центра и независимые депутаты. Остальные 12 партий и организаций, принимавших участие в выборах, мест в Сейме не получили („Голос Литвы” 1992, 25 ноября - 1 декабря).

25 По социальному происхождению депутатов новый литовский парламент очень отличался от первых парламентов независимых Эстонии и Латвии. Среди депутатов эстонского парламента уроженцев столицы было $35 \%$, деревень 19\%, среди депутатов латвийского парламента - соответственно 34 и 29\%. (см.: A. Stenn, Consolidation and competence: research on the politics of recruiting political elites in the Baltic States, ,Journal of Baltic Studies” 1996, v. XXVII, №. 2, p. 150).

${ }^{26}$ В Эстонии средний возраст депутата - 46 лет, в Латвии - 48 (см:. A. Stenn, op. cit., p. 149). 
Успех ДПТЛ был, прежде всего, протестным голосованием провинции против Вильнюса и деревни против города. Особую активность проявили поддерживающие ДПТЛ представители старшего поколения (модель голосования, очень сходная с той, при которой в России голосуют за КПРФ). Кроме того, как и следовало ожидать, поддержку ДПТЛ оказали польские и русские районы ${ }^{27}$.

Очень показательно, что в канун выборов победу ДПТЛ практически никто не предсказывал. Результаты опросов резко отличались от итогов голосования. В ситуации, сложившейся в Литве в ходе избирательной кампании, люди просто опасались заявлять о себе как о сторонниках ДПТЛ.

Председателем сейма стал лидер ДПТЛ Бразаускас, а спустя пару месяцев, 14 февраля 1993 г., литовцам предстояло избрать прямым голосованием президента. Свою кандидатуру на этот пост выдвинул Бразаускас. После некоторых колебаний Ландсбергис, оценив свои шансы, объявил, что не будет баллотироваться. В качестве оппонента Бразаускаса в предвыборную кампанию включился поддерживаемый „Саюдисом” С. Лозорайтис, сын литовских эмигрантов, проживающих в США, и посол Литвы в Вашингтоне.

Многим избирателям импонировали европейские манеры и стиль жизни Лозорайтиса (его жена была итальянка и сам он многие годы провёл в Риме). Этот человек как бы воплощал собой „Литву, которую мы потеряли", то есть ту Литву, какой она могла бы быть, если бы не ее присоединение к СССР. Помимо прочего, привлекали и его неангажированность местной политикой, нежелание присоединяться к какой-либо одной политической силе, а также всяческое подчеркивание необходимости достижения согласия (в случае, если его выберут, Лозарайтис предлагал назначить Бразаускаса премьер-министром). Не удивительно, что в результате Лозорайтиса поддержали, за исключением ДПТЛ, почти все партии, том числе даже центристы, которых стало тревожить растущее влияние Бразаускаса.

Но все „плюсы” Лозорайтиса очень легко переходили в „минусы”. Простым литовцам было все-таки трудно проголосовать за человека, который, покинув Литву еще юношей (он родился в 1924 г.), в общей

27 V. Gaidys, Rinkimai Lietuvoje: Sociologines Vertinimas, Lietuvos nacionalinai interesai ir jos politine sistema. Konferencijos medziaga, Vilnius 1994, p. 107. 
сложности провел в ней всего несколько недель. В глазах широких масс населения Бразаускас был полностью „свой”, в то время как его соперник выглядел слишком „чужим”. Кроме того, Лозорайтис допустил серьёзный „промах”. При всей своей умеренности он вдруг заявил о возможности „возвращения” Литве Калининграда, что Бразаускас охарактеризовал как бессмысленную провокацию в отношении России.

На выборах Бразаускас набрал 60,17\% голосов, а Лозорайтис только $38,7 \%$.

В 2004 г. страны Балтии стали полноправными членами Европейского Союза. Их „возвращение в Европу”, в отличие от стран Центральной Европы, шло параллельно со всплесками национализма, связанными со страхами вновь потерять только что восстановленную независимость. В Эстонии и Латвии эти страхи связывались с наличием многочисленных русских меньшинств, в Литве они питались подозрительностью и враждебностью новой правой элиты по отношению к бывшим коммунистам.

Литовское национальное движение было наиболее радикальным среди прибалтийских республик и находилось под сильным влиянием национализма и авторитарных тенденций межвоенного периода, нашедших свое воплощение в режиме Сметоны. Однако эти тенденции противоречили идеи „возвращения в Европу”, неразрывно связанной с полной демократизацией политической жизни. Чтобы интегрироваться в Европу, литовцам, таким образом, необходимо было преодолеть авторитаризм новых лидеров - национал-демократов, приведших их к независимости. Это во многом объясняет триумфальную победу в 1992 г. бывшей коммунистической партии А. Бразаускаса - Демократической партии Труда (позднее Социал-демократической партиии). Победа бывших коммунистов и поражение национал-демократов в Литве ознаменовали переход к системе ротации у власти различных политических сил и стабильному демократическому развитию.

\section{Summary}

In 2004 the Baltic countries will become full members of the European Union. This 'return to Europe' began in 1991 but initially, in contrast to the countries of Central Europe, in the Baltic states it was accompanied by the upsurge of the nationalist fe- 
elings connected with the fears of losing the newly born independence. In Estonia and Latvia these fears were focused first of all on the presence of the big Russian minorities, whereas in Lithuania they were rather nourished by the suspicions and hostility of the new rightist political elite towards the former communists.

The Lithuanian national movement was the most radical among the movements of the Baltic nations and it was influenced by the nationalism of the inter-war period with its authoritarian tendencies which culminated in the regime of Smetonas. These trends were in conflict with the idea of the 'return to Europe' which was inseparable from full democratization of the political life. So in order to integrate with the new Europe, Lithuanians needed to overcome these trends of their leadership which let them win independence. In many aspects this explains the triumphal victory in 1992 of the Democratic Labour Party (later the Social-Democratic Party) whose leader was the last head of the Lithuanian communists. So, paradoxically, the victory of the former communists and the defeat of the national - democratic Saudis (the first in the series of the democratic rotations of power in Lithuania) was an important step to create the full-fledged and stable democratic system on the path to Europe.

\section{Streszczenie}

W 2004 roku kraje bałtyckie zostaną pełnoprawnymi członkami Unii Europejskiej. Ich ,powrót do Europy” rozpoczął się w 1991, jednakże początkowo, inaczej niż w krajach Europy Środkowej, towarzyszyło mu nasilenie nastrojów nacjonalistycznych związanych z obawami przed utraceniem dopiero co narodzonej niepodległości. W Estonii i na Łotwie lęki te związane były przede wszystkim z obecnością znaczącej mniejszości rosyjskiej, natomiast na Litwie wynikały głównie z podejrzliwości i wrogości nowej prawicowej elity politycznej wobec dawnych komunistów.

Litewski ruch narodowościowy był najbardziej radykalnym ruchem w państwach nadbałtyckich. Wynikało to z nacjonalistycznych nastrojów okresu międzywojennego oraz autorytarnych tendencji, których kulminacją był reżim Smetonów. Tendencje takie zaprzeczały idei ,,powrotu do Europy”, nierozerwalnie związanego z pełną demokratyzacją życia politycznego. W celu osiągnięcia pełnej integracji z nową Europą Litwini musieli przezwyciężyć te tendencje swoich elit rządzących, co pozwoliło im wywalczyć niepodległość. Stanowi to w wielu aspektach wyjaśnienie triumfalnego zwycięstwa, jakie w 1992 roku odniosła Demokratyczna Partia Pracy (późniejsza Partia Socjaldemokratyczna), której przewodził dawny komunista, oraz porażki narodowych demokratów (pierwszej z serii demokratycznych zmian u sterów Litwy) będących ważnym krokiem w kierunku stworzenia dojrzałej i stabilnej demokracji wiodącej do Europy. 